\title{
Perancangan Sistem Pakar Diagnosis Penyakit pada Bayi dengan Metode Forward Chaining Berbasis Android
}

\author{
http://dx.doi.org/10.28932/jutisi.v5i1.877
}

\author{
Viviliani $^{\# 1}$, Radius Tanone ${ }^{\# 2}$ \\ ${ }^{\#} J$ urusan Teknik Informatika, Universitas Kristen Satya Wacana \\ Jl. Dr. O Notohamidjojo, Kel.Blotongan, Kec. Sidorejo, Salatiga \\ ${ }^{1}$ vivilianiiii@gmail.com \\ \#Jurusan Teknik Informatika, Universitas Kristen Satya Wacana \\ Jl. Dr. O Notohamidjojo, Kel.Blotongan, Kec. Sidorejo, Salatiga \\ ${ }^{2}$ radius. tanone@uksw. edu
}

\begin{abstract}
In infancy, the age of 0-12 months is a very important period in the process of human growth and development. The process of growth and development at this time affects the child's growth and development in the next period and to reduce mortality in infants. Quick and precise information needs from a baby health expert are needed. The method used in making this expert system is forward chaining, where the system is driven by existing facts. These facts are obtained from the patient's physical condition, or referred to as symptoms. With the existence of an android-based expert system, users everywhere can access to the internet and connect. The process of extracting knowledge by means of interviews. Based on the analysis, this expert system has a percentage of program eligibility for use by laymen is $82.7 \%$. Besides that, based on the results of the questionnaire, the ease of the program also gets a large percentage as well
\end{abstract}

Keywords - Android Application, Baby Disease, Forward Chaining, Expert System.

\section{Pendahuluan}

Pada masa bayi 0-12 bulan merupakan periode yang sangat penting dalam proses tumbuh kembang manusia. Proses tumbuh kembang pada masa tersebut mempengaruhi tumbuh kembang anak diperiode selanjutnya serta untuk menurunkan angka kematian pada bayi. Kebutuhan informasi yang cepat dan tepat dari seorang pakar kesehatan bayi sangatlah dibutuhkan [1]. Pada tahun 2016, hasil riset Badan Pusat Statistik (BPS) mencatat bahwa Angka Kematian Bayi (AKB) mencapai 25,5. Artinya, ada sekitar 25,5 kematian setiap 1.000 bayi yang lahir. Selama beberapa tahun belakangan, AKB di Indonesia mengalami penurunan, tetapi masih termasuk tinggi dibandingkan negara tetangga seperti Malaysia dan Singapura yang sudah di bawah 10 kematian per 1.000 kelahiran bayi. Kematian bayi merupakan salah satu indikator sensitif untuk mengetahui derajat kesehatan suatu negara dan bahkan untuk mengukur tingkat kemajuan suatu bangsa. Tingginya kematian bayi pada usia nol hingga satu tahun menunjukkan masih rendahnya kualitas sektor kesehatan di negara tersebut [2].

Berdasarkan hasil wawancara dengan dr. Srie Bengawani perancangan sistem pakar dalam mendiagnosis penyakit anak sangatlah penting dikarenakan pengetahuan orang tua tentang penyakit pada bayi masih terbatas jika anak mengalami gejala suatu penyakit maka orang tua akan memeriksakan anaknya ke tempat pelayanan kesehatan. Akan tetapi, jam pelayanan kesehatan Rumah Sakit Ibu dan Anak Mutiara Bunda di Salatiga terbatas pada waktu praktek dokter. Dengan meluasnya teknologi smartphone di masyarakat, maka mendorong pemanfaatan teknologi informasi tersebut untuk membantu di bidang kesehatan. Oleh karena itu, dengan adanya suatu aplikasi sistem pakar dapat membantu orang tua untuk mengenali gejala-gejala suatu penyakit yang diderita bayi. Pemanfaatan teknologi ini dapat membantu orang tua dalam melakukan pencegahan dan pengobatan segera pada balita yang sakit. Penyampaian informasi sistem pakar ini menggunakan perangkat mobile. Proses pembuatan aplikasi menggunakan sistem berbasis android. Salah satu profil yang diprediksikan oleh banyak ahli akan memberikan evolusi yang cukup signifikan bagi teknologi telekomunikasi yang bergerak secara menyeluruh [1].

Pertumbuhan perangkat mobile berbasis android ini bergerak mengikuti perkembangan aplikasi-aplikasi baru yang muncul silih berganti. Mengapa memilih membuat aplikasi diagnosis penyakit bayi pada platfrom android dikarenakan hampir setiap manusia memiliki smartphone android sehingga jika para orang tua ingin melakukan diagnosis orang tua tinggal membuka aplikasinya di smartphone dimanapun dan kapan pun ketika dibutuhkan 
karena bersifat mobile. Pada penelitan ini dibuat sistem pakar untuk mendiagnosis penyakit yang sering terjadi pada bayi yang meliput apnea, demam, ruam popok, kuningan, batuk pilek, infeksi saluran napas atas, sembelit, gastroentritis akut, diare. Sistem pakar yang dibuat berbasis android dengan menggunakan metode forward chaining.

Berdasarkan masalah tersebut, maka rumusan masalah untuk penelitian ini adalah bagaimana merancang sebuah aplikasi sistem pakar yang mudah dan dimengerti oleh user terhadap diagnosis penyakit bayi. Tujuan dari penelitian adalah agar dapat memberikan solusi kepada masyarakat, memberikan manfaat sebagai media informasi dan sistem pendamping untuk mendiagnosis jenis-jenis penyakit pada bayi, mengembangkan wawasan keilmuan dan meningkatkan pemahaman tentang struktur dan sistem kerja dalam pengembangan aplikasi pada sistem operasi android, sebagai konstribusi positif untuk kemajuan wawasan keilmuan teknologi informasi untuk pengembangan pada masa yang akan datang. Batasan masalah dalam penelitian ini adalah sistem yang dirancang adalah sistem pakar dan berbasis android dan hanya fokus pada penyakit bayi pada usia $0-12$ bulan.

\section{TINJAUAN PUSTAKA}

Penelitian yang berkaitan dalam penelitian perancangan basis data dan penelitian yang berjudul "Sistem Pakar Untuk Mendiagnosis Penyakit pada Balita dengan Menggunakan Metode Certainty Factor", pada penelitian ini menggunakan metode certainty factor berbasis android pada sistem yang dihasilkan dapat mengeluarkan hasil perhitungan valid yang sama dengan perhitungan manual, sehingga proses identifikasi penyakit dapat dilakukan dengan cepat dan akurat. Manfaat dari penelitian ini adalah proses pendiagnosis penyakit pada balita dengan menggunakan aplikasi sistem pakar dengan menggunakan metode certainty factor bisa lebih cepat dibandingkan dengan tanpa menggunakan aplikasi sistem pakar dan bisa bertindak seperti para pakar [3].

Penelitian lainnya yang berjudul "Aplikasi Sistem Pakar Untuk Mendiagnosis Penyakit Anak (Balita) Dengan Menggunakan Metode Forward Chaining" Sistem pakar ini menggunakan metode inferensi forward chaining dalam perancangan aplikasi ini menggunakan Waterfall. Metode Waterfall diawali dengan analisis data, perancangan sistem, pengkodean menggunakan Visual Basic 6.0, pengujian sistem dengan black box test. Manfaat yang di dapat dari penelitian ini adalah hasil yang akan diuji dengan konsultasi dengan sistem yang menunjukkan bahwa sistem mampu menentukan penyakit dan perawatan sementara, berdasarkan gejala yang dipilih oleh pengguna [4].

Penelitian lain yang berjudul "Sistem Pakar untuk Penyakit Anak Menggunakan Metode Forward Chaining" metode yang digunakan dalam pembuatan sistem pakar ini adalah forward chaining dan backward chaining, di mana sistem digerakkan oleh fakta-fakta yang ada. Fakta tersebut diperoleh dari kondisi fisik pasien, atau disebut dengan gejala. Dalam pembuatan sistem pakar ini diperlukan penggalian knowledge oleh engineer yang bersumber pada pakar, dalam hal ini adalah dokter. Berdasarkan analisis, sistem pakar ini memiliki presentase kelayakan program untuk digunakan oleh orang awam adalah sebesar 85.4\% [5].

Pada penelitian lain yang berjudul "Aplikasi Sistem Pakar untukMendiagnosis Penyakit pada Bayi Menggunakn Piranti Mobile" metode yang digunakan adalah forward chaining pada aplikasi ini dikembangkan menggunakan J2ME yaitu Java 2 Micro Edition sebuah pengembangan bahasa Java yang digunakan pada perangkat yang memiliki memory kecil seperti pada ponsel, pager atau PDA (Personal Digital Asistent) pada databasenya disimpan didalam program aplikasi sehingga tidak memakai admin dan jika database dirubah hal ini dilakukan oleh programmer. Berdasarkan analisis hasil yang didapatkan adalah sistem pakar memberikan informasi yang diperlukan untuk memanfaatkan pelayanan dokter sebaik mungkin [6].

Dalam penelitian ini yang digunakan adalah metode forward chainig serta fokus pada penyakit bayi dan berbasis android. Pada penelitian sebelumnya dapat dilihat bahwa dengan metode forward chaining memiliki kelebihan yaitu penelusuran yang akan dimulai berdasarkan gejala yang ada, sehingga dari informasi-informasi gejala tersebut dapat diketahui apakah penyakit yang diderita serta solusi pengobatannya. Pada penelitian ini pengembangan aplikasi berbasis Mobile android memiliki kelebihan yaitu sebuah sistem operasi yang sifatnya open source, sehingga merupakan salah satu operating system (OS) yang mudah untuk dikembangkan karena memiliki sistem open source selain itu memiliki user interface yang menarik dan pengembangan aplikasi ini menggunakan bahasa react native serta database firebase.

\section{A. React Native}

Merupakan framework open source besutan Facebook yang memungkinkan developer untuk mengembangkan trully native app atau aplikasi yang benar-benar terasa native baik Android ataupun $i O S$ dengan menggunakan javascript. Hal ini memungkinkan karena react native benar-benar menggunakan native component Android \& iOS yang dikemas dalam javascript, dan bukan menggunakan webview seperti pada teknologi mobile web terdahulu seperti "cordova/phonegap". Selain itu react native juga membantu mempercepat proses development, karena hanya membutuhkan javascript saja untuk membangun sebuah UI yang stable. Walaupun masih dalam tahap pengembangan dan percobaan, react native sudah banyak diimplementasikan pada aplikasi-aplikasi terkenal seperti Facebook, Instagram, SoundCloud dan masih banyak lagi [7].

Beberapa kelebihan yang dimiliki react native adalah sebagai berikut: 
- memiliki user experience yang baik sehingga menghasilkan antarmuka look dan feel yang alami dengan baik.

- kualitas dan keamanannya terjamin karena di kontrol oleh vendor masing-masing dan memiliki akses penuh ke perangkat mobile.

- Dengan react native, kita bisa membuat aplikasi Android dan $i O S$ hanya dalam satu framework.

- Untuk user interface, react native sangat fleksibel dengan mudah sehingga dapat customize tampilan seperti warna, tinggi, padding, margin, font size dan lain-lain.

- Dalam proses development ketika melakukan running aplikasi sekali saja, untuk merefresh atau mencompile updatean koding dengan tinggal menekan shortcut double R.

\section{B. Firebase}

Firebase merupakan sebuah layanan infrastruktur backend-as-a-service (BaaS) yang diakuisisi oleh Google pada Oktober 2014 silam. Firebase menawarkan kemudahan kepada para pengembang perangkat lunak dalam membangun aplikasi yang lebih baik serta mengembangkan bisnis yang sukses melalui seluruh fitur komplementernya. Saat ini, firebase sudah memiliki fitur analytics, cloud messaging, authentication, realtime database, storage, hosting, test lab, crash reporting, notifications, remote config, app indexing, dynamic links, invites, adwords, dan admob. Seluruh fitur tersebut dikemas dalam sebuah SDK firebase tunggal sehingga dengan kemudahan yang ditawarkan para pengembang perangkat lunak dapat fokus untuk memecahkan masalah customer melalui perangkat lunak yang dibuatnya dan tidak menghabiskan banyak waktu dalam membangun infrastruktur yang kompleks [8].

Beberapa kelebihan yang dimiliki firebase adalah sebagai berikut:

- Tersedia versi Free, sehingga para developer dapat mencoba layanan firebase tanpa batasan waktu.

- Cepat dan responsif.

- Tanpa SQL, firebase menggunakan JSON.

- SDK tersedia untuk Android, iOS, JavaScript, Java, Objective-C, swift dan Node.js.

- Powerful API untuk menyimpan dan sinkronasi.

- API relatif mudah dimengerti.

- Realtime backend.

\section{Sistem Pakar}

Sistem pakar adalah salah satu cabang dari kecerdasan buatan Artificial Intelligence (AI). Salah satu definisi populer dari kecerdasan buatan adalah "membuat komputer berpikir seperti manusia." Ketika suatu sistem berhasil melalui tes yang diujikan, maka sistem tersebut dianggap sebagai strong $A I$. Istilah strong $A I$ digunakan dengan anggapan bahwa $A I$ harus berdasarkan dasar logika yang kuat daripada yang dissebut sebagai weak $A I$, yaitu berdasarkan jaringan neural buatan, algoritma genetic, dan metode evolusioner. Sistem pakar adalah sebuah aplikasi dari teknologi kecerdasan buatan yang sangat baik [9].

\section{Forward chaining}

Forward chaining adalah salah satu metode dari sistem pakar yang mencari atau menelusuri solusi melalui masalah. Dengan kata lain metode ini melakukan pertimbangan dari fakta-fakta yang kemudian berujung pada sebuah kesimpulan yang berdasarkan pada fakta-fakta. Metode ini merupakan kebalikan dari metode backward chaining yang melakukan pencarian yang berawal dari hipotesis menuju ke fakta-fakta untuk mendukung hipotesis tersebut. Forward chaining disebut juga bottom-up reasoning atau pertimbangan dari bawah ke atas, karena metode ini mempertimbangkan dari bukti-bukti pada level bawah, fakta-fakta, menuju ke kesimpulan pada level atas yang berdasarkan pada fakta-fakta [10]. Dengan kata lain, prosesnya dimulai dari facts (fakta-fakta yang ada) melalui proses interface fact (penalaran fakta-fakta) menuju suatu goal (suatu tujuan). Metode ini juga disebut menggunakan aturan IF-THEN dimana premise (IF) menuju conclusion (THEN) atau dapat juga dituliskan sebagai berikut. Ada dua pendapat mengenai pelaksanaan metode ini. Pertama dengan cara membawa seluruh data yang didapat ke sistem pakar. Kedua dengan membawa bagian-bagian penting saja dari data yang didapat ke sistem pakar. Cara pertama lebih baik digunakan jika sistem pakar terhubung dengan proses otomatis dan penerima seluruh data dari database. Cara kedua menghemat waktu serta biaya dengan mengurangi data dan mengambil data yang dianggap perlu. Sebagai contoh, seperti kasus pada kedua metode di atas, maka berdasarkan metode ini langah-langkah yang diambil:

\section{$\mathrm{R} 1:$ IF $A$ and $C$, THEN $B$ \\ $\mathrm{R} 2:$ IF $D$ and $C$, THEN $F$ \\ R3 : IF $B$ and E, THEN $F$ \\ $\mathrm{R} 4:$ IF B, THEN $C$ \\ R5 : IF F, THEN G}

Kedua jenis strategi ini akan mengarah pada suatu kesimpulan. Namun, efisiensinya tergantung dari kondisi masalah yang dihadapi [11]. Pada artikel ilmiah ini mengambil cara kedua.

\section{E. Android}

Menurut Nazruddin Android adalah aplikasi sistem operasi untuk telepon seluler yang berbasis Linux. Android menyediakan platform terbuka bagi para pengembang untuk menciptakan aplikasi mereka sendiri untuk digunakan oleh bermacam piranti bergerak [12].

\section{METODE PERANCANGAN}

Metode penelitian yang digunakan adalah metode penelitian dan pengembangan (Research and Development/R\&D). Untuk dapat menghasilkan produk tertentu digunakan penelitian yang bersifat analisis 
kebutuhan dan untuk menguji keefektifan produk tersebut supaya dapat berfungsi di masyarakat luas, maka diperlukan penelitian dalm menguji keefektifan produk tersebut [13].
Langkah-langkah penelitian dan pengembangan pada penelitian ini dapat ditunjukkan pada Gambar 1.

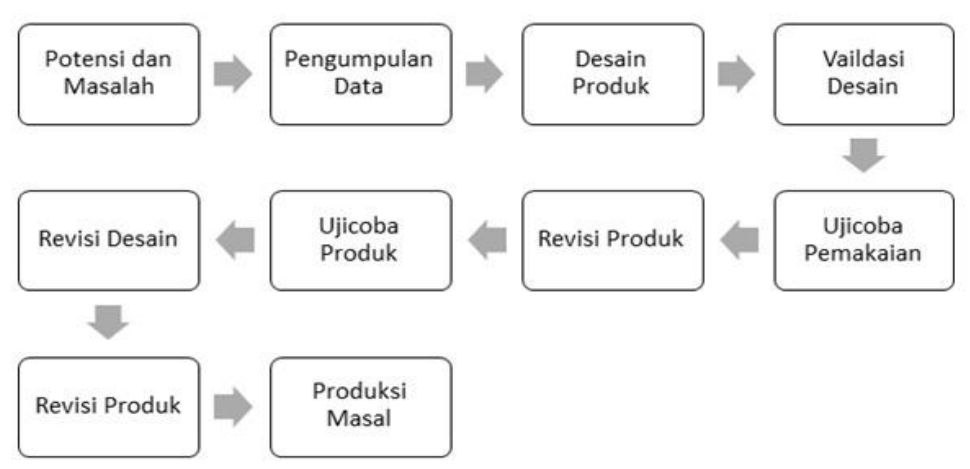

Gambar 1. Metode Penelitian [13]

Secara ringkas dapat dijelaskan bahwa proses tiap tahapan penelitian yang dilakukan adalah sebagai berikut :

1. Potensi dan Masalah

Penelitian dapat berangkat dari adanya potensi atau masalah. Berdasarkan hasil wawancara dengan dr. Srie Bengawani perancangan di Rumah Sakit Ibu dan Anak Mutiara Bunda potensi yang diangkat menjadi masalah pada penelitian ini adalah belum adanya aplikasi diagnosis penyakit pada bayi di Salatiga dikarenakan pengetahuan orang tua tentang penyakit pada bayi masih terbatas jika anak mengalami gejala suatu penyakit maka orang tua akan memeriksakan anaknya ke tempat pelayanan kesehatan. Akan tetapi, jam pelayanan kesehatan dirumah sakit
Salatiga terbatas pada waktu praktek dokter. Penelitian ini digunakan untuk membantu masyarakat di Salatiga dalam mendiagnosis penyakit bayi.

2. Pengumpulan Data

Pengumpulan data dengan cara mengumpulkan literatur, jurnal, browsing internet dan bacaan-bacaan yang ada kaitannya dengan topik baik berupa textbook atau paper dan melakukan wawancara kepada pakar penyakit anak.

3. Desain Produk

Perancangan desain produk aplikasi diagnosis penyakit bayi menggunakan UML yang meliputi use case diagram, activity diagram dan class diagram.

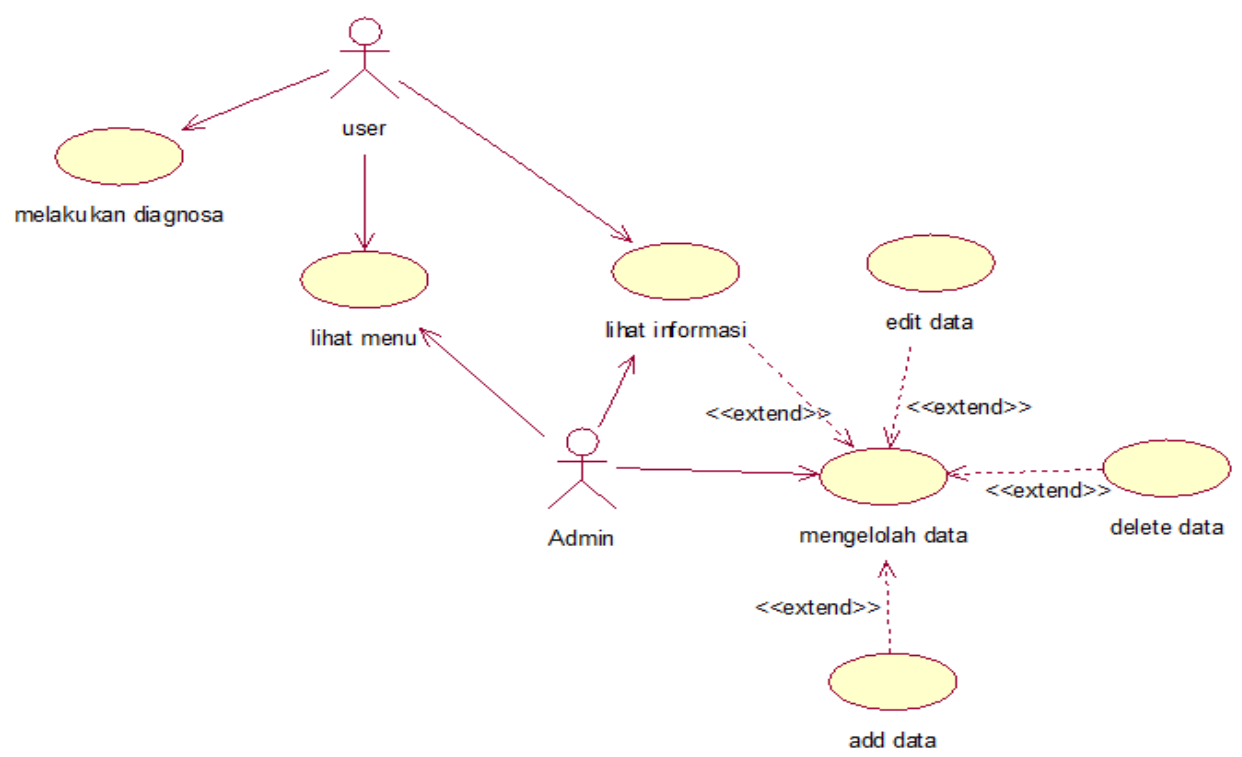

Gambar 2 Use Case Diagram Diagnosis Penyakit Bayi 
Pada Gambar 2 menunjukkan admin memiliki hak untuk mengelola data penyakit bayi, admin disini adalah seorang dokter spesialis penyakit anak. Admin melakukan login melalui database firebase secara langsung. Admin sendiri dapat melihat informasi dan melihat menu. Sedangkan user dapat melakukan konsultasi diagnosis secara langsung tanpa perlu login ke aplikasi android. Dan user dapat melihat informasi data penyakit bayi.

Activity diagram diagnosis penyakit bayi dari segi user yang telah dirancang ditunjukkan pada Gambar 3.

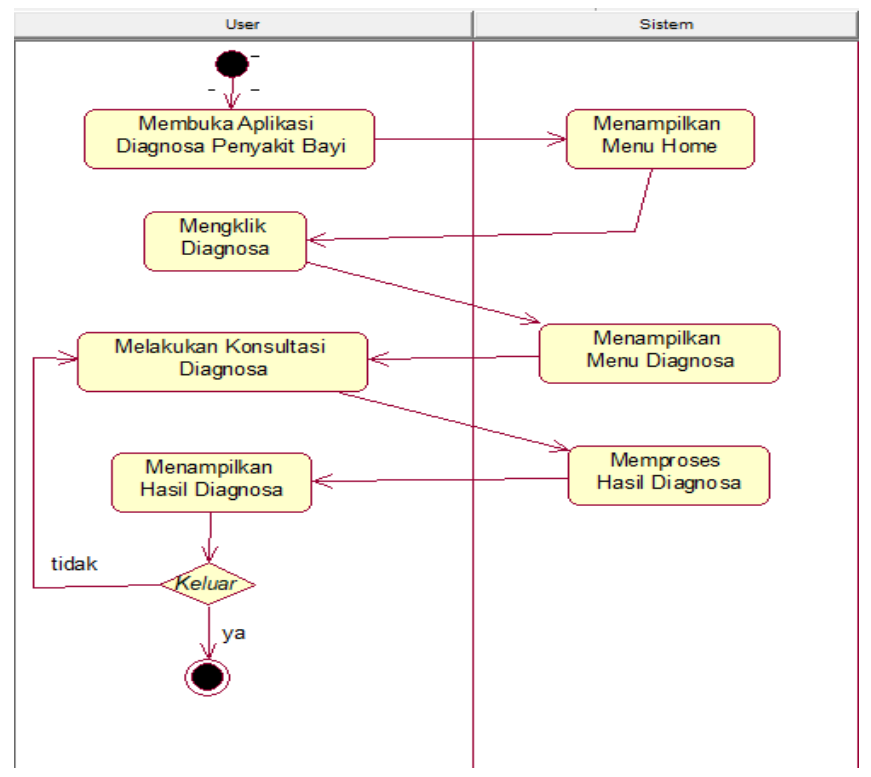

Gambar 3 Activity Diagram User Ketika Ingin Melakukan Diagnosis

Pada Gambar 3 adalah activity diagram ketika user membuka aplikasi maka sistem akan manampilkan menu home di menu home terdapat pilihan informasi atau diagnosis, ketika user melakukan diagnosis maka sistem akan memproses hasil diagnosis dan akan menampilkan hasil diagnosis beserta gejalah dan solusinya.

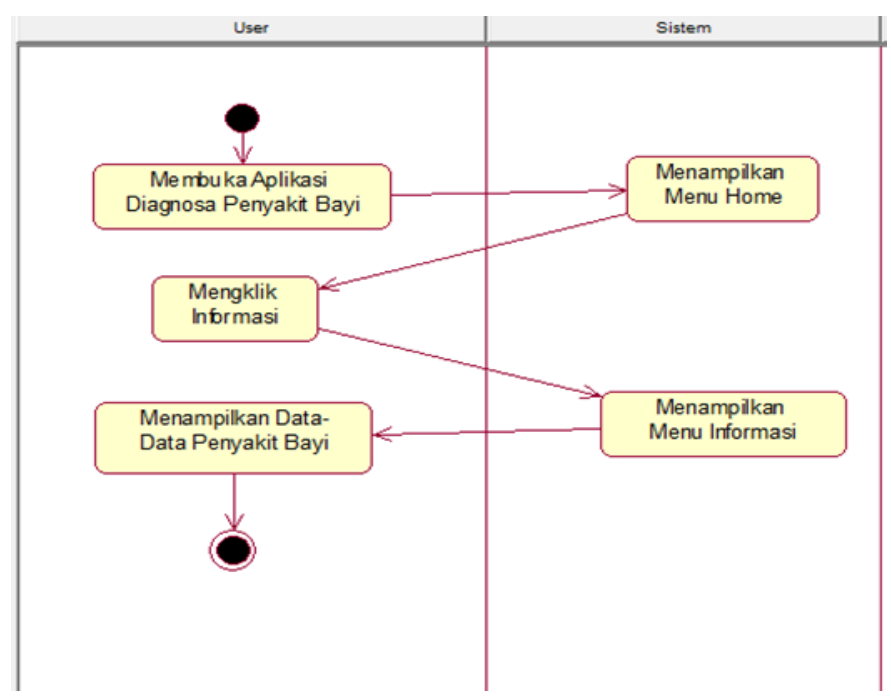

Gambar 4 Activity Diagram User Informasi

Pada Gambar 4 adalah activity diagram ketika user membuka aplikasi maka sistem akan manampilkan menu home dimenu home sendiri terdapat pilihan informasi atau diagnosis, ketika user memilih Informasi maka sistem akan menampilkan data-data penyakit bayi.

class diagram diagnosis penyakit bayi yang telah dirancang ditunjukkan pada Gambar 5. 


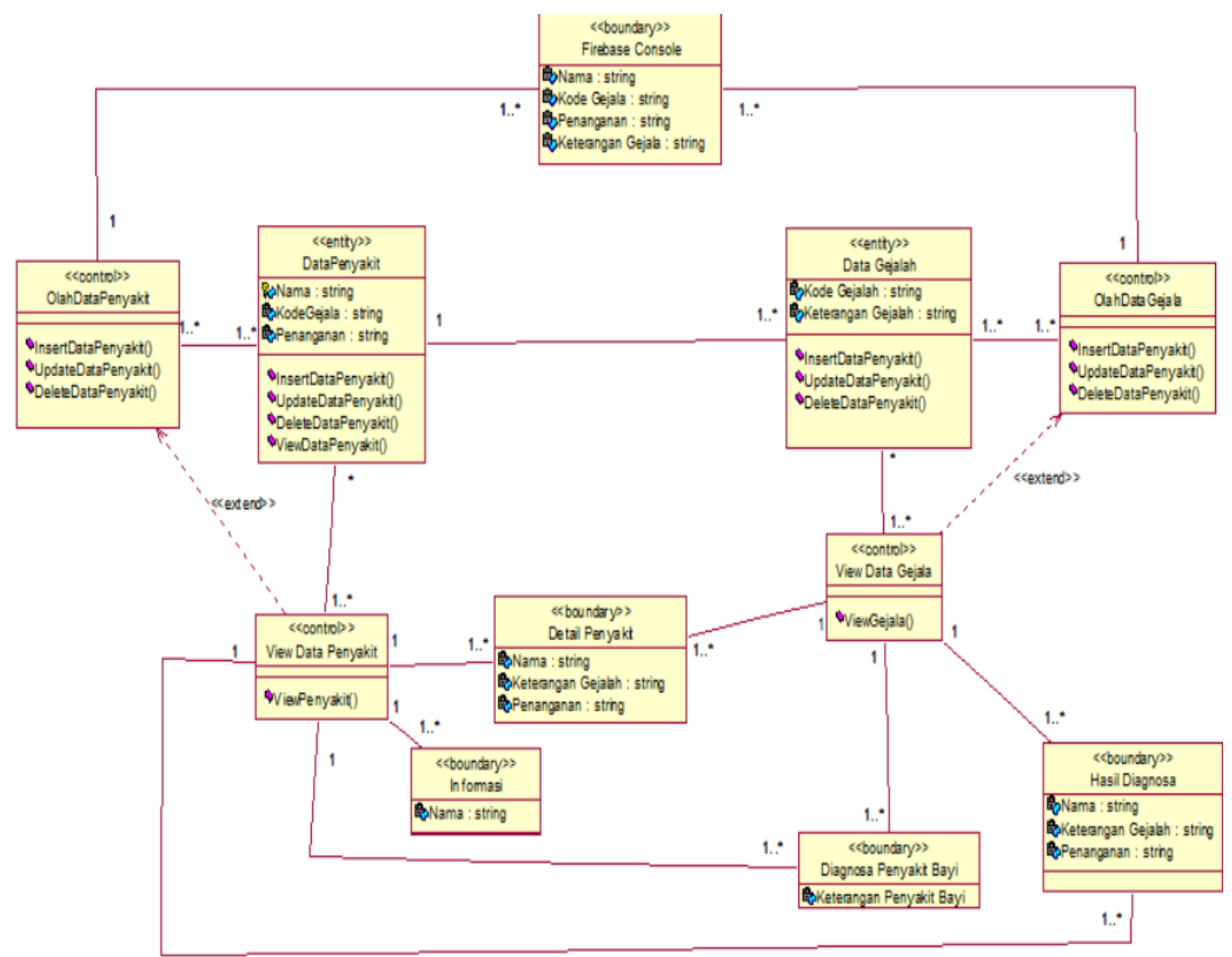

Gambar 5 class diagram Diagnosis Penyakit Bayi

Pada Gambar 5 adalah class diagram, Sistem Pakar Diagnosis Penyakit Bayi memiliki sebelas class yang terdiri dari 2 entity class yaitu Data_Penyakit dan Data_Gejala; 5 boundry class yaitu Firebase_Console, Informasi, Detail_Penyakit, Detail_Penyakit_Bayi dan Hasil_Diagnosis; dan 4 control class yaitu Olah_Data_Penyakit, Olah_Data_Gejala, View_Data_Gejala dan View_Data_Penyakit. Setiap class memiliki attribute dan behavior masing-masing serta memiliki relasi satu sama lain sesuai hubungan antar class. 4. Validasi Desain

Validasi desain adalah suatu proses kegiatan yang bertujuan untuk menilai rancangan suatu produk. Dalam hal ini validasi desain dilakukan dengan analisi logis/analisis internal. Yaitu melakukan wawancara terhadap ahli pakar.

5. Revisi Desain

Setelah validasi desain berupa hasil wawancara selesai divalidasi, maka akan dapat diketahui kelemahannya. Pakar ahli akan menemukan beberapa konten yang perlu diubah, direvisi, atau dibuang. Kemudian diperbaiki untuk kemudian dikonstruksi menjadi sebuah parameter dalam sistem pakar diagnosis penyakit bayi.

6. Uji Coba Pemakaian

Setelah desain selesai dibuat maka akan memproses pembuatan aplikasi dan di uji coba pemakaian pada kelompok terbatas.

7. Revisi Produk

Revisi produk ini dilakukan, apabila dalam perbaikan kondisi nyata terdapat kekurangan dan kelebihan. Kelemahan-kelemahan produk yang ditemukan dalam sampel terbatas selanjutnya diperbaiki untuk memperoleh produk yang lebih sempurna.

8. Uji Coba Produk

Desain produk yang sudah dibuat tidak dapat langsung dicoba terlebih dahulu. Akan tetapi harus lah dibuat terlebih dahulu, sehingga menghasilkan produk dan produk itu lah 
yang nantinya akan dicoba. Pengujian bisa dilaksanakan menggunakan alpha test dan beta test, alpha test yaitu strategi pengujian yang perangkat lunak yang paling umum digunakan supaya terhindar dari cacat dan kegagalan penggunaan. Beta test yaitu pengujian yang dilakukan secara langsung dan acak untuk memvalidasi kegunaan, fungsi, kompatibilitas, dan uji reliabitas dari software yang ada.

9. Revisi produk sistem.

Perbaikan produk apabilah ditemukan kelemahan pada

10. Produksi Massal

Akhir dari penelitian ini adalah sebuah sistem pakar diagnosis penyakit bayi dengan metode forward chaining. Meskipun sistem ini tidak ditujukan sepenuhnya untuk menggantikan fungsi ahli pakar penyakit anak, tetapi diharapkan dapat mempermudah para orang tua dalam mendiagnosis penyakit bayi.

TABEL I

DATA PENYAKIT BAYI

\begin{tabular}{|l|l|}
\hline \multicolumn{1}{|c|}{ Kode } & \multicolumn{1}{|c|}{ Nama Gejala } \\
\hline P01 & Apnea \\
\hline P02 & Demam \\
\hline P03 & Ruam Popok \\
\hline P04 & Kuningan \\
\hline P05 & Batuk Pilek \\
\hline P06 & Infeksi Saluran Pernafasan Atas (ISPA) \\
\hline P07 & Sembelit \\
\hline P08 & Gastroentritis Akut \\
\hline P09 & Diare \\
\hline
\end{tabular}

Berdasarkan pada Tabel I adalah data penyakit bayi, terdapat 9 penyakit bayi yang ada dari hasil wawancara yang telah dilakukan. Dari data yang akan dimasukan kedalam program yang telah dibuat

TABEL II

GEJALA PENYAKIT BAYI

\begin{tabular}{|l|l|}
\hline \multicolumn{1}{|c|}{ Kode } & \multicolumn{1}{c|}{ Nama Gejala } \\
\hline G01 & Bayi bernapas terengah-engah \\
\hline G02 & Bayi sering tersedak \\
\hline G03 & Wajah atau tubuh bayi membiru \\
\hline G04 & Bayi menjadi lemas \\
\hline G05 & Suhu tubuh bayi diatas 37,5 derajat celcius \\
\hline G06 & Lesuh dan tidak bersemngat saat bermain \\
\hline G07 & Bayi menjadi rewel \\
\hline
\end{tabular}

\begin{tabular}{|l|l|}
\hline \multicolumn{1}{|c|}{ Kode } & \multicolumn{1}{c|}{ Nama Gejala } \\
\hline G08 & $\begin{array}{l}\text { Bercak kemerahan pada bagian area bokong, } \\
\text { paha, dan alat kelamin }\end{array}$ \\
\hline G09 & Kulit bayi terasa panas saat disentuh \\
\hline G10 & Kulit bayi menguning \\
\hline G11 & Bayi bersin-bersin \\
\hline G12 & Hidung bayi meler atau tersumbat \\
\hline G13 & Batuk-batuk \\
\hline & $\begin{array}{l}\text { Menunjukkan gejala dehidrasi, misalnya } \\
\text { bibir kering dan tidak buang air kecil selama } \\
\text { 6 jam terakhir }\end{array}$ \\
\hline G14 & Bayi kehilangan nafsu makan \\
\hline G15 & Perut bayi kembung \\
\hline G16 & Jika diraba perut bayi menjadi keras \\
\hline G17 & Kehilangan berat badan \\
\hline G18 & Mengalami demam ringan \\
\hline G19 & Muntah-muntah \\
\hline G20 & Warna Feses Hitam \\
\hline G21 & \\
\hline
\end{tabular}

Berdasarkan pada Tabel II terdapat 21 gejalah penyakit bayi. Data tersebut didapatkan dari hasil wawancara dengan dr. Srie Bengawani beliau adalah dokter spesialis anak di Rumah Sakit Ibu dan Anak Mutiara Bunda yang ada di kota Salatiga.

TABEL III

RELASI PENYAKIT DAN GEJALA

\begin{tabular}{|c|c|c|c|c|c|c|c|c|c|}
\hline Kod & P0 & P0 & P0 & P0 & P0 & P0 & P0 & P0 & P0 \\
\hline G01 & V & & & & & V & & & \\
\hline G02 & V & & & & & & & & \\
\hline G03 & V & & & & & & & & \\
\hline G04 & V & & & & & & & & \\
\hline G05 & & V & & & & & & & \\
\hline G06 & & V & & V & & & & & V \\
\hline G07 & & V & V & V & & & V & & V \\
\hline G08 & & & V & & & & & & \\
\hline G09 & & & V & & & & & & \\
\hline G10 & & & & V & & & & & \\
\hline G11 & & & & & V & & & & \\
\hline G12 & & & & & V & V & & & \\
\hline G13 & & & & & V & & & & \\
\hline G14 & & & & & & V & & & \\
\hline G15 & & & & & & V & V & & \\
\hline G16 & & & & & & & V & & \\
\hline G17 & & & & & & & V & & \\
\hline G18 & & & & & & & & V & \\
\hline G19 & & & & & & & & V & \\
\hline G20 & & & & & & & & & V \\
\hline G21 & & & & & & & & & V \\
\hline
\end{tabular}


Berdasarkan Pada Tabel III merupakan tabel yang menjelaskan relasi hubungan gejala dan penyakit. Pada tabel ini dapat dilihat gejala-gejala pada setiap penyakit bayi yang akan digunakaan dalam sistem pakar diagnosis penyakit bayi.

TABEL IV

AtURAN Diagnosis PENYAKIT BAyI

\begin{tabular}{|c|c|}
\hline Kode & Nama Gejala \\
\hline IF & G01 \\
\hline And & G02 \\
\hline And & G03 \\
\hline And & G04 \\
\hline Then & P01 \\
\hline IF & G05 \\
\hline And & G06 \\
\hline And & G07 \\
\hline Then & P02 \\
\hline IF & G07 \\
\hline And & G08 \\
\hline And & G09 \\
\hline Then & P03 \\
\hline IF & G06 \\
\hline And & G07 \\
\hline And & G10 \\
\hline Then & P04 \\
\hline IF & G06 \\
\hline And & G07 \\
\hline And & G10 \\
\hline Then & P04 \\
\hline IF & G11 \\
\hline And & G12 \\
\hline And & G13 \\
\hline Then & P05 \\
\hline IF & G01 \\
\hline And & G12 \\
\hline And & G14 \\
\hline And & G15 \\
\hline Then & P06 \\
\hline IF & G07 \\
\hline And & G15 \\
\hline And & G16 \\
\hline And & G17 \\
\hline Then & P07 \\
\hline
\end{tabular}

\begin{tabular}{|c|c|}
\hline Kode & Nama Gejala \\
\hline IF & G18 \\
And & G19 \\
Then & P08 \\
\hline IF & G06 \\
And & G07 \\
And & G20 \\
And & G21 \\
Then & P09 \\
\hline
\end{tabular}

Berdasarkan pada Tabel IV merupakan tabel hasil pengolahan Tabel III relasi penyakit dan gejala menjadi rumus aturan forward chaining yang digunakaan dalam sistem pakar diagnosis penyakit bayi. Setiap aturan memiliki syarat-syarat dimana setiap syarat harus terpenuhi agar hasil kode penyakit dapat keluar. Oleh karena itu digunakan operasi logika And dimana operasi logika akan bernilai benar jika seluruh syarat bernilai benar.

\section{HASIL DAN PEMBAHASAN}

Berdasarkan perancangan sistem yang telah dirancang sebelumnya dilakukan implementasi dan pengujian aplikasi Diagnosis Penyakit Bayi. Implementasi dan pengujian sistem dilakukan dengan tujuan memastikan apakah hasil perancangan sudah sesuai dengan harapan serta dapat menyelesaikan masalah yang dihadapi.
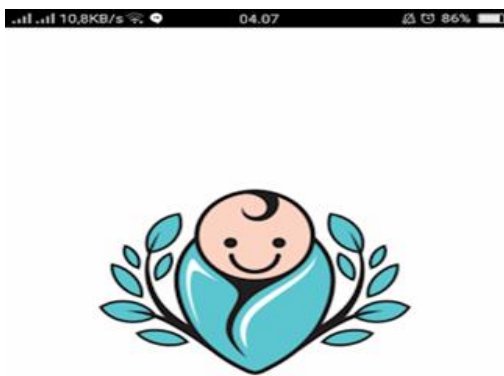

Sistem Pakar Diagnosa
Penyakit Bayi

Gambar 6 Halaman Splash Screen

Gambar 6 merupakan tampilkan halaman splash screen. Ketika user membuka aplikasi pertama kali maka aplikasi akan memunculkan layar splash screen logo bayi dan tulisan sistem pakar diagnosis penyakit bayi. Splash screen ini merupakan tampilan antar muka yang berfungsi untuk 
memberitahu user bahwa aplikasi sedang menjalankan proses pembukaan aplikasi.

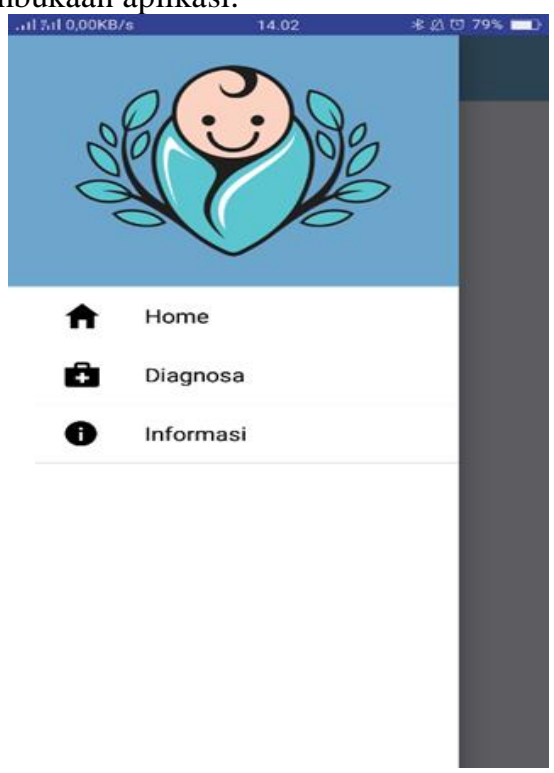

Gambar 7 Halaman Side Menu Aplikasi

Gambar 7 merupakan tampilan halaman Side Menu aplikasi diagnosis penyakit bayi. Side Menu ini akan terbuka jika icon burger pada Header dipilih. Side Menu ini berfungsi untuk navigasi dari satu halaman ke halaman yang lain. Terdapat list icon dan nama dari halaman home, informasi dan diagnosis yang jika dipilih maka halaman tersebut akan terbuka.

DAFTAR PENYAKIT BAYI
INFORMASI
Apnea
Demam $52 \%$ व
Ruam popok
Kuningan
Batuk pilek
Infeksi Saluran Pernafasan Atas
(ISPA)
Sembelit
Gastroentritis Akut
Diare
Gambar 8 Halaman Informasi

Gambar 8 merupakan tampilan antar muka Halaman Informasi pada halaman ini user dapat melihat daftar informasi nama penyakit bayi yang disajikan dalam tampilan listview. Jika salah satu item pada list dipilih maka halaman detail penyakit akan dibuka seperti yang ditunjukan pada gambar dikiri. Data penyakit diambil dari database firebase yang dikelola oleh admin sistem.
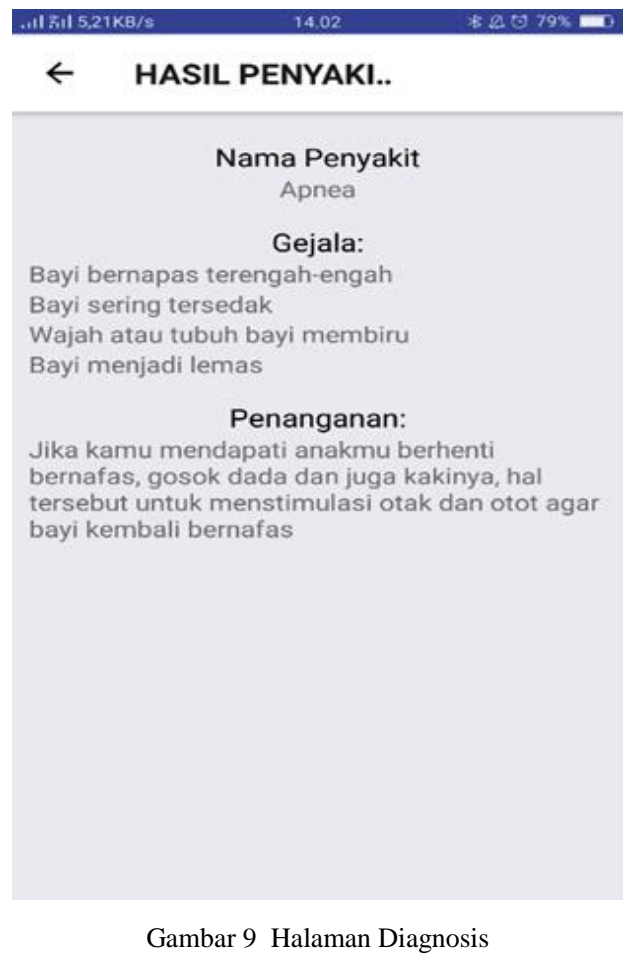

Gambar 9 merupakan halaman diagnosis disini user diminta untuk memilih apakah bayi mengalami gejala sesuai dengan pertanyaan-pertanyaan gejala yang ditampilkan. Apabila user menjawab "iya" maka gejala tersebut akan disimpan. Setelah semua pertanyaan dijawab oleh user maka sistem akan mencari pada database apakah terdapat penyakit yang memiliki gejala-gejala sesuai dengan gejalagejala yang disimpan berdasarkan jawaban user. Jika ditemukan penyakit dengan gejala-gejala yang sesuai maka halaman hasil diagnosis penyakit akan muncul menampilkan nama penyakit, daftar gejala penyakit, dan cara penanganan. Jika tidak ditemukan penyakit dengan gejala-gejala yang sesuai maka akan muncul alert yang memberitahukan kepada user bahwa tidak ditemukan penyakit pada database dengan gejala-gejala tersebut. 
KODE PROGRAM IV

DIAGNOSIS PENYAKIT

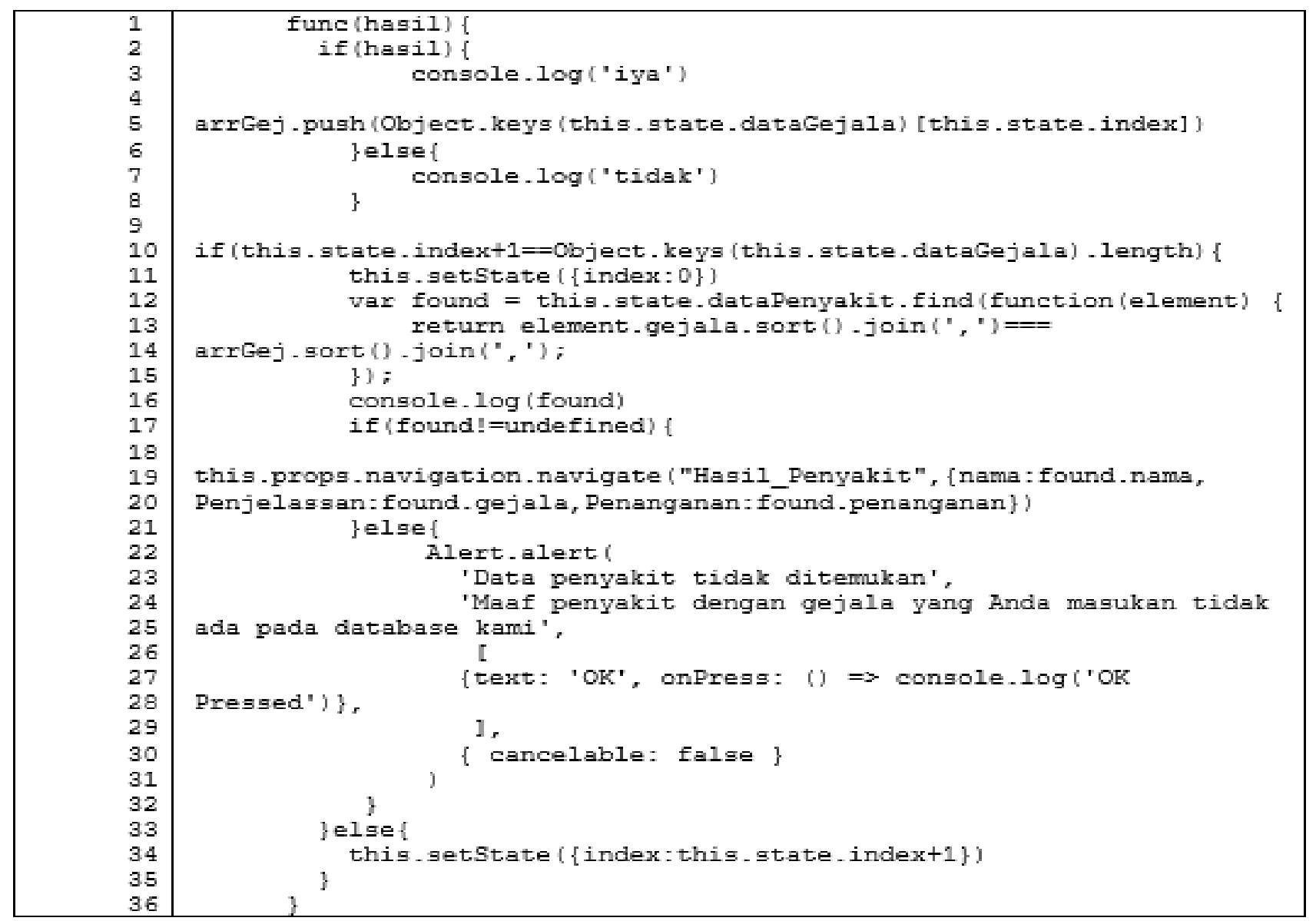

Kode Program I merupakan fungsi saat user melakukan diagnosis penyakit bayi. Fungsi ini dijalankan pada saat user memasukan jawaban untuk setiap gejala yang di tampilkan. Baris 2-7 digunakan untuk melihat input apa yang dimasukan oleh user sesuai dengan parameter function, Apabila user memasukan hasil iya maka gejala tersebut akan disimpan dalam array. Baris 10-36 berfungsi untuk melihat apakah semua pertanyaan gejala telah dijawab oleh user. Jika belum semua pertanyaan dijawab maka index pertanyaan akan ditambah sesuai dengan fungsi pada baris 34 dan pertanyaan gejala selanjutanya akan ditampilkan. jika semua pertanyaan gejala telah dijawab maka index pertanyaan akan diatur ulang dan akan dicari pada database

penyakit apa yang sama dengan array gejala yang disimpan sebelumnya. Sesuai dengan penerapan metode Forward Chaining dimana dilakukan pengecekan setiap hasil gejala yang ada dengan rule gejala setiap penyakit yang ada pada database, hal ini ditunjukan pada baris 12-14 dimana dibuat sebuah variable untuk menampung hasil pencarian dengan pengecekan apakah array gejala yang ditampung sama dengan salah satu array gejala penyakit pada database. jika ditemukan penyakit yang sesuai maka halaman hasil penyakit akan dibuka dengan detail penyakit yang telah dimasukan pada parameter tersebut sesuai dengan fungsi pada baris 19. Jika tidak ditemukan hasil maka akan ditampilkan alert dengan pesan bahwa tidak ditemukan data penyakit dengan gejala yang telah dimasukan sesuai dengan fungsi pada baris 22-32.

Pengujian sistem program pada penelitian ini menggunakan metode black box testing, yaitu pengujian yang dilakukan dengan menjalankan atau mengeksekusi unit atau modul, kemudian diamati apakah hasil dari unit itu sesuai dengan output yang diinginkan. Hasil pengujian Black Box Testing pada sisi aplikasi android mobile user dapat dilihat pada Tabel V.

TABEL V

Hasil PENGUJian BLACK BOX TESTING

\begin{tabular}{|c|c|c|c|}
\hline Halaman & $\begin{array}{l}\text { Sekenario } \\
\text { Pengujian }\end{array}$ & $\begin{array}{l}\text { Output Yang } \\
\text { Diharapkan }\end{array}$ & Hasil \\
\hline Home & $\begin{array}{l}\text { Membuka } \\
\text { side menu }\end{array}$ & Side menu terbuka & Berhasil \\
\hline \multirow[t]{2}{*}{ Informasi } & $\begin{array}{l}\text { Membuka } \\
\text { side menu }\end{array}$ & Side menu terbuka & Berhasil \\
\hline & $\begin{array}{l}\text { Melihat } \\
\text { semua list }\end{array}$ & $\begin{array}{l}\text { Semua item daftar } \\
\text { penyakit bayi }\end{array}$ & Berhasil \\
\hline
\end{tabular}




\begin{tabular}{|c|c|c|c|}
\hline & $\begin{array}{l}\text { item daftar } \\
\text { penyakit bayi }\end{array}$ & & \\
\hline & $\begin{array}{l}\text { Memilih } \\
\text { salah satu } \\
\text { item } \\
\text { penyakit bayi }\end{array}$ & $\begin{array}{l}\text { Halaman Detail } \\
\text { Penyakit terbuka } \\
\text { dengan detail } \\
\text { penyakit yang seusai }\end{array}$ & Berhasil \\
\hline \multirow[t]{3}{*}{ Diagnosis } & $\begin{array}{l}\text { Membuka } \\
\text { side menu }\end{array}$ & Side menu terbuka & Berhasil \\
\hline & $\begin{array}{l}\text { Melihat } \\
\text { semua } \\
\text { pertanyaan } \\
\text { gejala } \\
\text { penyakit }\end{array}$ & $\begin{array}{l}\text { Semua item } \\
\text { pertanyaan gejala } \\
\text { berhasil ditampilkan }\end{array}$ & Berhasil \\
\hline & $\begin{array}{l}\text { Memilih } \\
\text { salah satu } \\
\text { jawaban } \\
\text { untuk } \\
\text { pertanyaan } \\
\text { gejala }\end{array}$ & $\begin{array}{l}\text { Jika Bukan } \\
\text { merupakan } \\
\text { pertanyaan terakhir } \\
\text { maka pertanyaan } \\
\text { Selanjutnya akan } \\
\text { muncul. Jika } \\
\text { merupakan } \\
\text { pertanyaan terakhir } \\
\text { maka akan muncul } \\
\text { hasil diagnosis dan } \\
\text { pertanyaan gejala } \\
\text { akan diulang }\end{array}$ & Berhasil \\
\hline
\end{tabular}

Pengujian ketepatan hasil diagnosis dilakukan menggunakan metode white box testing, yaitu pengujian yang dilakukan dengan menjalankan atau mengeksekusi unit atau modul dengan pengetahuan cara sistem berkerja, kemudian diamati apakah hasil dari unit itu sesuai dengan output yang diinginkan. Hasil pengujian white box testing pada sisi aplikasi android mobile user dapat dilihat pada Tabel VI.

TABEL VI

Hasil Pengujian White Box Testing

\begin{tabular}{|c|c|c|c|}
\hline Halaman & $\begin{array}{l}\text { Sekenario } \\
\text { Pengujian }\end{array}$ & $\begin{array}{l}\text { Output Yang } \\
\text { Diharapkan }\end{array}$ & Hasil \\
\hline \multirow[t]{3}{*}{ Diagnosis } & $\begin{array}{l}\text { Menjawab } \\
\text { "iya" pada } \\
\text { gejala G01, } \\
\text { G02, G03 dan } \\
\text { G04 serta } \\
\text { menjawab } \\
\text { tidak pada sisa } \\
\text { pertanyaan } \\
\text { gejala }\end{array}$ & $\begin{array}{l}\text { Halaman Hasil } \\
\text { Diagnosis muncul } \\
\text { menampilkan } \\
\text { penyakit P01 yaitu } \\
\text { Apnea }\end{array}$ & Berhasil \\
\hline & $\begin{array}{l}\text { Menjawab } \\
\text { "iya” pada } \\
\text { gejala G05, } \\
\text { G06 dan G07 } \\
\text { serta menjawab } \\
\text { tidak pada sisa } \\
\text { pertanyaan } \\
\text { gejala }\end{array}$ & $\begin{array}{l}\text { Halaman Hasil } \\
\text { Diagnosis muncul } \\
\text { menampilkan } \\
\text { penyakit P02 yaitu } \\
\text { Demam }\end{array}$ & Berhasil \\
\hline & $\begin{array}{l}\text { Menjawab } \\
\text { "iya" pada } \\
\text { gejala G07, } \\
\text { G08 dan G09 } \\
\text { serta menjawab }\end{array}$ & $\begin{array}{l}\text { Halaman Hasil } \\
\text { Diagnosis muncul } \\
\text { menampilkan } \\
\text { penyakit P03 yaitu } \\
\text { Ruam Popok }\end{array}$ & Berhasil \\
\hline
\end{tabular}

\begin{tabular}{|c|c|c|c|}
\hline Halaman & $\begin{array}{l}\text { Sekenario } \\
\text { Pengujian }\end{array}$ & $\begin{array}{l}\text { Output Yang } \\
\text { Diharapkan }\end{array}$ & Hasil \\
\hline & $\begin{array}{l}\text { tidak pada sisa } \\
\text { pertanyaan } \\
\text { gejala }\end{array}$ & & \\
\hline & $\begin{array}{l}\text { Menjawab } \\
\text { "iya" pada } \\
\text { gejala G06, } \\
\text { G07 dan G10 } \\
\text { serta menjawab } \\
\text { tidak pada sisa } \\
\text { pertanyaan } \\
\text { gejala }\end{array}$ & $\begin{array}{l}\text { Halaman Hasil } \\
\text { Diagnosis muncul } \\
\text { menampilkan } \\
\text { penyakit P04 yaitu } \\
\text { Kuningan }\end{array}$ & Berhasil \\
\hline & $\begin{array}{l}\text { Menjawab } \\
\text { "iya" pada } \\
\text { gejala G11, } \\
\text { G12 dan G13 } \\
\text { dan menjawab } \\
\text { tidak pada sisa } \\
\text { pertanyaan } \\
\text { gejala }\end{array}$ & $\begin{array}{l}\text { Halaman Hasil } \\
\text { Diagnosis muncul } \\
\text { menampilkan } \\
\text { penyakit P05 yaitu } \\
\text { Batuk Pilek }\end{array}$ & Berhasil \\
\hline & $\begin{array}{l}\text { Menjawab } \\
\text { "iya” pada } \\
\text { gejala G01, } \\
\text { G12, G14 dan } \\
\text { G15 serta } \\
\text { menjawab } \\
\text { tidak pada sisa } \\
\text { pertanyaan } \\
\text { gejala }\end{array}$ & $\begin{array}{l}\text { Halaman Hasil } \\
\text { Diagnosis muncul } \\
\text { menampilkan } \\
\text { penyakit P06 yaitu } \\
\text { ISPA }\end{array}$ & Berhasil \\
\hline & $\begin{array}{l}\text { Menjawab } \\
\text { "iya” pada } \\
\text { gejala G07, } \\
\text { G15, G16 dan } \\
\text { G17 serta } \\
\text { menjawab } \\
\text { tidak pada sisa } \\
\text { pertanyaan } \\
\text { gejala }\end{array}$ & $\begin{array}{l}\text { Halaman Hasil } \\
\text { Diagnosis muncul } \\
\text { menampilkan } \\
\text { penyakit P07 yaitu } \\
\text { Sembelit }\end{array}$ & berhasil \\
\hline & $\begin{array}{l}\text { Menjawab } \\
\text { "iya" pada } \\
\text { gejala G18 dan } \\
\text { G19 serta } \\
\text { menjawab } \\
\text { tidak pada sisa } \\
\text { pertanyaan } \\
\text { gejala }\end{array}$ & $\begin{array}{l}\text { Halaman Hasil } \\
\text { Diagnosis muncul } \\
\text { menampilkan } \\
\text { penyakit P08 yaitu } \\
\text { Gastroentritis Akut }\end{array}$ & berhasil \\
\hline & $\begin{array}{l}\text { Menjawab } \\
\text { "iya” pada } \\
\text { gejala G06, } \\
\text { G07, G20 dan } \\
\text { G21 serta } \\
\text { menjawab } \\
\text { tidak pada sisa } \\
\text { pertanyaan } \\
\text { gejala }\end{array}$ & $\begin{array}{l}\text { Halaman Hasil } \\
\text { Diagnosis muncul } \\
\text { menampilkan } \\
\text { penyakit P09 yaitu } \\
\text { Diare }\end{array}$ & berhasil \\
\hline
\end{tabular}

Pengujian dilakukan dengan mengajukan kuesioner kepada pakar yaitu tenaga kesehatan (dokter anak) yang berjumlah 15 orang. Adapun pernyataan yang diajukan ke responden sebagai berikut: 
1. Aplikasi diagnosis penyakit bayi yang dibangun telah menampilkan dan menghasilkan hasil olahan data yang sesuai. (Hasil jawaban pertanyaan 1, dapat dilihat pada Tabel VII)

2. Anda puas atas hasil aplikasi diagnosis penyakit bayi berbasis android (Tingkat kepuasan pengguna yaitu hasil jawaban pertanyaan 2, dapat dilihat pada Tabel VIII)

TABEL VII

Tabel Hasil Kuesioner Pakar PertanyaAn 1

\begin{tabular}{|c|c|c|c|}
\hline Keterangan & $\begin{array}{c}\text { Skor Likert } \\
(\text { Pn) }\end{array}$ & $\begin{array}{c}\text { Ahli } \\
\text { Pakar }\end{array}$ & Skor (Rs) \\
\hline Sangat Setuju (SS) & 5 & 6 & 30 \\
\hline Setuju (S) & 4 & 5 & 20 \\
\hline Cukup Setuju (CS) & 3 & 4 & 12 \\
\hline Tidak Setuju (TS) & 2 & - & - \\
\hline $\begin{array}{c}\text { Sangat Tidak Setuju } \\
\text { (STS) }\end{array}$ & 1 & - & - \\
\hline Jumlah & & $\mathrm{T}=10$ & $\begin{array}{c}\mathrm{TS}= \\
62\end{array}$ \\
\hline
\end{tabular}

Dari hasil analisis pada Tabel IV dilakukan perhitungan dengan menggunakan skala Likert, yaitu:

IKK (Indeks Kesesuaian Kasar $)=\frac{T S(\text { Total Skor })}{Y(\text { Skor Tertinggi })}$

$100 \%$

$=62 / 75 \times 100=82,7 \%$, termasuk kategori sangat setuju.

TABEL VIII

TABEl HASIL KUESIONER PAKAR PERTANYAAN 2

\begin{tabular}{|c|c|c|}
\hline Keterangan & Responden & $\begin{array}{c}\text { Presentase } \\
(\%)\end{array}$ \\
\hline Sangat Setuju (SS) & 6 & $40 \%$ \\
\hline Setuju (S) & 5 & $33,3 \%$ \\
\hline Cukup Setuju (CS) & 4 & $26,7 \%$ \\
\hline Tidak Setuju (TS) & - & - \\
\hline
\end{tabular}

\section{KESIMPULAN DAN SARAN}

Dari hasil uji coba dan yang dilakukan dapat ditarik kesimpulan, Perancangan Sistem Pakar Diagnosis Penyakit pada Bayi dengan Metode Forward Chaining Berbasis Android yaitu aplikasi sistem pakar yang dibangun dapat mempermudah orang tua dalam memberikan informasi mengenai suatu penyakit dan gejala-gejalanya serta solusi, aplikasi sistem pakar yang dibangun dapat memberikan informasi mengenai tindakan atau pengobatan dari setiap penyakit yang berhasil. Pada aplikasi sistem pakar ini juga memberikan kemudahan dalam penggunaan serta dapat digunakan dimana saja karena diaplikasikan dalam smartphone android. Sistem pakar ini juga mampu memberikan informasi penanganan awal bagi para orang tua yang jauh dari tempat praktek dokter, jam praktek yang terbatas maupun keterbatasan tenaga medis. Sistem dapat mengeluarkan hasil perhitungan valid yang sama dengan perhitungan manual, sehingga proses identifikasi penyakit dapat dilaukan dengan cepat dan akurat. Sistem pakar ini mampu untuk mengetahui nama penyakit, penyebab, dan penanganan terhadap penyakit yang sedang dialami oleh bayi. Dari hasil uji skala Lickert, sebesar $82.7 \%$ masuk kategori sangat setuju, maka dapat disimpulkan bahwa aplikasi sistem pakar yang dibangun sudah sesuai dengan tujuannya yaitu dapat melakukan Diagnosis penyakit sehingga dapat membantu, memberikan informasi tentang suatu penyakit beserta gejalanya dan menampilkan olahan data yang sesuai dan jumlah responden yang setuju puas atas hasil aplikasi Diagnosis penyakit bayi sebear $40 \%$, sedangkan jumlah responden yang sangat setuju sebesar $33.3 \%$ dan jumlah responden yang cukup setuju sebesar $26.7 \%$ sehingga hal ini dapat membantu masyarakat yang ada di Salatiga serta Rumah Sakit Ibu dan Anak Mutiara Bunda dalam mendiagnosis penyakit bayi.

Saran aplikasi sistem pakar diagnosis penyakit berbasis mobile smartphone sebaiknya lebih banyak dikembangkan untuk hewan, tumbuhan, usia dewasa, dan usia lanjut. Pada aplikasi yang dikembangkan ini juga masih sederhana, untuk pengembangan selanjutnya diharapkan bisa menampilkan fitur user agar bisa melakukan konsultasi langsung kepada dokter anak yaitu sebagai admin. Pada penyakit bayi yang dibahas dalam sistem pakar ini juga dibatasi hanya beberapa penyakit saja untuk kedepannya diharapkan mungkin bisa menambahkan data-data penyakit dan gejalahnya. Serta perbaikan user interface sesuai kebutuhan pengembangan sistem selanjutnya seperti perbaikan desain dan kelengkapan fasilitas-fasilitas didalam aplikasi.

\section{DAFTAR PUSTAKA}

[1] Kusnadi, Sanjaya Nanang dan Muslihin Ihin. Sistem Pakar Diagnosa Penyakit Paru Pada Anak Dengan Metode Forward Chaining, 1, 2016.

[2] Sekretariat Jenderal Kementerian Kesehatan Indonesia. Profil Kesehatan Indonesia Tahun 2016. Jakarta: Kementerian Kesehatan Indonesia, 2016.

[3] Yunik, Asih Budi. Sistem Pakar Untuk Mendiagnosa Penyakit Pada Balita Dengan Menggunakan Metode Certainty Factor, 2015.

[4] Mulyani, Evi Dewi Sri dan Restianie, Irna Nur. Aplikasi Sistem Pakar Untuk Mendiagnosa Penyakit Anak (Balita) Dengan Menggunakanmetode Forward Chaining, 2016.

[5] Suwarso,Gideon Abram Filando. Sistem Pakar untuk Penyakit Anak Menggunakan Forward Chaining, 2015.

[6] Sulastri, Eri, Zuliarso. Aplikasi Sistem Pakar untuk Mendiagnosa Penyakit pada Bayi Menggunakan Piranti Mobile. 2-13, 2017.

[7] Eisenman, Bonnie, Learning React Native. California : O'Reilly Media, Inc, 2015.

[8] Ilham, Mirza. Pengenalan Google Firebase Untuk Hybrid Mobile Apps Berbasis Cordova. 21-22, 2017. 
[9] Giarratano, J. C. dan Riley, G. D. Expert Systems Principles and Programming Fourth Edition, 167-173. Boston, Massachusetts: Thomson Course Technology, 2005.

[10] Kusrini. Aplikasi Sistem Pakar, 15. Yogyakarta: Andi Offset, 2008.

[11] Purwono, Edi. Sistem Analisis, ANDI. Yogyakarta, 2007.
[12] Safaat, Nazruddin. Android Pemrograman Aplikasi Mobile Smartphone, 2012.

[13] Sugiyono, Metode Penelitian Pendidikan Pendekatan Kuantitatif, Kualitatif, dan R\&D. Bandung: Alfabet, 2009. 